International Research Journal of Management, IT \& Social Sciences
Available online at https://sloap.org/journals/index.php/irjmis/
Vol. 5 No. 4, July 2018, pages: $80 \sim 90$
ISSN: 2395-7492
https://doi.org/10.21744/irjmis.v5n4.266

\title{
Factors Affecting The Fishermen Household Income And Welfare
}

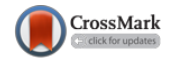

$\begin{array}{r}\begin{array}{c}\text { Alberto A.R. Lein }{ }^{a} \\ \text { Nyoman Djinar Setiawina }^{b}\end{array} \\ \hline \hline\end{array}$

Article history:

Received: 27 February 2018

Revised: 26 June 2018

Approved: 20 July 2018

Published: 26 July 2018

\section{Keywords:}

Welfare;

Revenue;

Fisherman;

Technology;

Total Catch;

Sales Fish Price;

Production Cost;

\begin{abstract}
The desire to realize a prosperous society in the true sense is a great goal to be achieved by the Indonesian people in the system of government of the Republic of Indonesia. The potential of fishery resources can actually be utilized to increase income which will be expected to improve the welfare of fishermen households. In fact, many fishermen still have not been able to increase their catch, so the income level of fishermen households does not increase so that the welfare of the fisherman's life is still not realized. The fishery sector is the mainstay for most people as if they depend on their fishing business. This phenomenon is occurring in most parts of Indonesia, including fishermen in the coastal area of East Flores. In relation to the phenomenon, then the research questions are 1). What is the effect of production cost, technology, selling price, and fish catch on the income of fishermen in East Flores Regency? 2). What is the effect of production cost, technology, selling price, and fish catch on the welfare of fishermen households in East Flores Regency? 3). Does the income of fishermen mediate the cost of production, technology, selling prices, and the fish caught on the welfare of fishermen households in East Flores District? Research objectives: 1). Analyzing, whether the factors of production costs, technology, the selling price of fish, and the catch of fish affect the income of fishermen in East Flores Regency? 2). Analyzing factors of production cost, technology, selling price, and fish catches have an effect on to fisherman household welfare in East Flores regency. 3). Analyzing whether fisherman's income mediates the influence of production cost factor, technology, selling price and fish catch on fisherman household's prosperity in East Flores Regency. The population of this study is 7,761 people. Sampling was conducted by applying "Slovin theory" so that the number of samples was 99 people. Proportionate Probability Sampling method was then applied in order to determine the number of respondents. The samples of 99 respondents were interviewed based on the questionnaires provided beforehand. In the interviews, the variables obtained consist of Production cost (IDR), technology (modern and traditional), sales price (IDR), and yields (Kg), Revenue (IDR), and welfare level (measured according to Standard Bureau of Statistics with 7 indicators, namely: consumption pattern, health, Education, Security, Love, Social and Culture). The cost of production, technology, selling price, and fish catch have a significant effect on fisherman's income. Fishermen income has a positive and significant impact on the welfare of fishermen households in East Flores Regency. Indirect effect analysis found that factor of production cost, technology, and fish catch have significant influence through fisherman income to fisherman household welfare in East Flores Regency.
\end{abstract}

\footnotetext{
${ }^{\text {a }}$ A Student at Master Program of Economics, Faculty of Economics and Business, Udayana University, Indonesia

${ }^{\mathrm{b}}$ Supervisor of the Thesis, Master Program of Economics, Faculty of Economics and Business, Udayana University
} 


\section{Author correspondence:}

Alberto A.R. Lein,

A Student at Masters' Program in Economics,

Faculty of Economics and Business, Udayana University, 80232,

Email address: leinalfrid@gmail.com

\section{Introduction}

The desire to realize a prosperous society in the true sense is a good goal to be achieved by the Indonesian people in the Government System of the Republic of Indonesia. Increasing the welfare of the population can be possible if the income of the population has increased enough to be able to meet basic needs for life. This means that food, clothing, housing, education, health, safety and so on are available and accessible to every citizen, thereby reducing the number of poor people. Fishermen make a living in order to earn income for the necessities of life. For its implementation, it needs some supplies and influenced by many factors to support the success of the activities. According to Salim (1999) factors that affect the income of fishermen include social and economic factors consisting of the amount of capital, the number of boats, the number of labor, distance to see and experience. Thus the income of fishermen based on the size of the volume of catch, there are still some other factors that contribute to determining it, that is technology, the selling price of fish and the catch of fish.

East Flores Regency is one of the regencies in East Nusa Tenggara Province which has a considerable fishery and marine potential with an area of East Flores sea area of approximately 3,818.32 km2. Data at the Office of Fisheries and Marine Affairs, East Flores Regency noted that from the East Flores sea research, there are various types of fish that have export value abroad such as to Japan and to Singapore. Types of fish that have a very good market in both countries are tuna or cangkalang fish and types of commercial fish such as groupers and snapper. In addition to the two types of fish that have overseas markets, the waters of East Flores also has the potential of other types of fish, such as tuna, kembang, selar, kite, kemang, teri, tembang, yellow tail, baronang, merlin, deho-deho, squid and a number of other fish species. With the natural potentials it has, East Flores Regency should be a top priority for the economic growth of its people. However, the people of East Flores Regency are among the fishermen of poor economic class. Increasing number of fishermen is a result of rapid population growth without jobs, and the number of people goes fishing. The increase in the number of fishermen also affects the income earned by fishermen. The number of fishermen in East Flores Regency is 7,761 people spread in 17 sub-districts.

Most of the people in East Flores Regency work as fishermen. But in fact, the income earned from the job has not been able to determine the level of their welfare. Most of the fishermen in East Flores Regency are traditional fishermen and fishermen laborers. Traditional fishermen are fishermen whose technology still uses traditional tools, and fisherman workers, are fishermen working on other people's fishing boats. When viewed from the technology used, it can be distinguished into two categories, namely the business of modern fishermen (fisherman labor) and the traditional fishing business. Modern fisherman businesses use more sophisticated fishing technology e.g by utilizing modern technology characterized by the use of motorized boats as a catch fleet equipped with a global positioning system (GPS) as a directional and fish finder whereas fishermen using traditional technology, the catch fleet used is not equipped with GPS and fish finder. The level of modernity is not solely due to the use of motors to drive boats but also the size of the used motorboats, as well as the level of exploitation and fishing gear used. The difference in the technological modernity of fishing gear will also affect their operational roaming capabilities.

The contribution of the fishery sub-sector to GRDP of East Flores Regency from year to year has increased, although the growth rate fluctuates. Despite this, the fishery sub-sector remains the sub-sector that has the greatest contribution to the Gross Regional Domestic Product of East Flores Regency and is a reliable sector compared to other sectors and sub-sectors. It continued to increase in 2012-2016, the GRDP in 2012 was 731,783.8 million and increased in 2016 amounted to $822,071.5$ million.

The data of the Fisheries and Maritime Affairs Office of East Flores Regency shows that the production of the marine fishery in 2013 was 13,810 tons and increased to 15,078 tons in 2017. Seen from the production of the marine fishery in East Flores Regency each year has increased, reflected in the life of the fisherman itself, because production

Lein, A. A., \& Setiawina, N. D. (2018). Factors affecting the fishermen household income and welfare. International Research Journal of Management, IT and Social Sciences, 5(4), 80-90. https://doi.org/10.21744/irjmis.v5n4.266 
is related to income, if production increases, and so does the income. However, in the reality, it can be seen from the social structure of fishermen community life in East Flores Regency, that it does not reflect a better income of fishermen.

According to Rambe in Purwanto (2009), the determinants of the optimal development of development resources are: (1) limited economic facilities and infrastructures, such as roads, fishery economic facilities and public-social facilities, (2) low quality of human resources, (3) limited fishing technology capacity, (4) limited access to capital and local economic product markets, (5) the absence of socioeconomic institutions that can be instruments of community development, (3) lack of capacity to manage their social welfare, and (6) the absence of an integrated coastal development commitment.

The problem of poverty in rural areas of East Flores Regency is caused by several factors, among others: population growth, low quality of human resources and low productivity. Salim (1984), stated that poverty is inherent in the poor, they are poor because they do not have production assets and the ability to increase productivity. They do not have production assets because they are poor, as a result, they are entangled in an endless circle of poverty. In addition, poverty is also a causality relationship which means that low income per capita causes high poverty rates. The poverty rate in East Flores Regency is still quite large, from 2013 to 2017 the rate has always not been fixed. In 2013 the poverty rate in East Flores was 8.11\%, in 2014 decreased to 7.85\%, in 2015 increased to 9.72\%, in 2016 was 10.30\% and in 2017 decreased to $9.89 \%$.

The main problem often experienced by fishermen in Flores Regency is the very low price of fish sales. The level of income that remains constant (tends to be constant) and hardly develops annually. The price of fish sales in East Flores Regency depends on the type of fish, the price of tuna sold to Japanese and Singaporean companies is IDR. $45,000 / \mathrm{kg}$ and the price of tuna fish is IDR. 25,000 / kg. Fish prices can sometimes go up and down depending on the season. In addition to tuna and grafted fish, they are not accepted in the company because they are perishable and are sold to the people of East Flores Regency. It is common that these fish are also sold to other areas outside East Flores Regency, for example, it is sold to the regions of Maumere, Ende, Bajawa, and Manggarai regencies at relatively cheap prices from IDR.250,000 / per box to IDR.300,000 / and always not permanent. The catches of traditional fishermen in East Flores Regency are different types of fish, namely kembang fish, squid, layang, selar, anchovies and tembang fish and other types of fish. Usually, the yields of fishing for traditional fishermen are sold at a price of IDR. 15,000 to IDR. 20,000 depending on the type and the size of the fish. From the sale price of very cheap fish causes the income of fishermen to tend to remain sluggish or not increase.

The low level of income of fishermen is a challenge in achieving the objectives, among others, to improve the welfare of fishermen. Poverty experienced by fishermen can only be overcome by fostering individual fishermen so that they can increase their income independently. Income will increase if the fishermen are willing to change consciously to increase their income. Poverty can be changed by increasing productivity. Because by increasing productivity, it will encourage a high-income increase so that welfare will also increase and daily needs can be fulfilled even the residual income can be saved to finance the future needs.

Increasing the welfare of the population can be done if the income of fishermen has increased enough so as to be able to meet basic needs for household life. This means that the needs of food, clothing, housing, health, security, etc. are available and easily accessible to every inhabitant so that in turn the poor population is always small in number. Fisheries resources can potentially be utilized to improve the living standards and welfare of fishermen households. But the reality is still quite a lot of fishermen who have not been able to improve the catch so that the income level of fishermen does not increase. This is in line with efforts to improve the standard of living of fishermen households and increase fish production that is directly or indirectly influenced by factors of production costs, labor, the technology used, fishing results and sales prices. Fisherman's welfare level is determined by bycatch and sales price. The number of catches is also reflected in the income received and the income is mostly for the consumption of the family. Thus the level of fulfillment of fishermen household consumption needs is largely determined by the income of the fishermen. The fishermen work with the aim of obtaining income for the needs of life. For implementation, some equipment is needed and is influenced by many factors to support the successful activities of fishing. According to Salim (1999), the factors that influence fisherman's income include social and economic sectors consisting of the amount of production cost, the amount of labor, work experience, technology, the catch and the selling price.

This study aims to observe and analyze the factors that affect fishermen's income and fishermen's household welfare, namely production cost, labor, technology, fishing result and selling price of fish. Factors in production costs are included in this study because income is strongly influenced by production costs. As it is known that in production factor theory, the amount of output/production that is later associated with income depends on the cost of production. 
This means that with production costs, fishermen can go fishing to catch fish. The bigger the production, the greater the cost of production or catches.

Technological factors used in fishing also affect fishermen's income. The bigger the motorboat used to go to sea, the greater the income of fishermen. The catch and sale price of fish greatly affect the amount of income earned by fishermen. The household income of fishermen will determine the consumption expenditure and the level of welfare. From the above description, this research will examine more about the income of fishermen in the title of the thesis that is "Analysis of Factors Affecting Revenue and Welfare of Fisherman Household in East Flores Regency of East Nusa Tenggara Province".

\section{Literature review}

\section{1) Production cost}

According to Irawan and Suparmoko (1979: 96), Production costs are all forms of wealth that can be used, directly or indirectly, in production to increase output. More specifically, it can be said that capital consists of goods made for the production process in the future. Capital as a driving force for economic development includes investment in technical knowledge, improvements in education, health, and expertise. Working capital is the number of funds used during a specified period that is intended to generate a short-term income (Current income) that corresponds to the main intent of starting a business. In starting their business, fishermen need enough capital to catch fish. The capital is needed to buy a boat, machine, fishing gear, and additional tools that can support to improve the catch.

2) Technology

Technologies related to equipment used by fishermen in fishing are non-engined boats and motorized boats, nets and fishing rods. Fishing equipment is the value of the equipment used such as boat prices, the price of fishing gear, and foodstuffs brought to sea and consumed at home. This is an input for fishermen in fishing, such as the amount of labor used in fishing.

Fishermen are categorized as someone whose job is to catch fish using simple fishing gear, ranging from fishing rods, nets, trawls, and so on. But in its development, it was categorized as a person who caught fish with a more modern tool, namely fishing boats with modern fishing gear. The more sophisticated the technology that fishermen use, the more productivity increases, meaning that the fishermen will earn a higher income.

\section{3) Selling Price}

According to Kotler (2001: 439) price is the amount of money charged on a product or service or the amount of value exchanged by consumers for benefits because of owning or using the product or service. Suhartati (2003) in microeconomic theory, the price is the price of a commodity (a particular good), whereas, in macroeconomic theory, it is connected with the price level as a whole. According to William.J.Stanton (1994) in Dinawan 2010, the price is the amount of value that consumers exchange for the benefit of owning or using other products or services set by the buyer or seller for a single price equal to all buyers. The Case \& Fair book mentions that the price is the amount sold by a per-unit product, and reflects some of the available paid by the public.

4) Catches of fish

Fishermen expect that the catch of fish always increases every day. This may lead to an increase in the income of fishermen. According to Suhartati in the book Theory of Microeconomics (2003: 139) that producers are considered will always choose the level of output $(\mathrm{Q})$ that can get maximum total profit i.e. conditions that maximize the difference between total revenue and total cost.

The theory can be applied in the life of fishermen, where if they can choose, fishermen will certainly choose the maximum level of output and continue to grow each day. Like the theory of total revenue (TR) proposed by Roger (2000: 163) that various prices per unit times the number of requests. This is the amount of income received by the seller of a valuable product, $\mathrm{P}$ for a number of $\mathrm{Q}$ units sold. Marginal income (MR) is defined as the amount of change in total income related to changes in the one-unit amount of sales. Based on Roger's theory, it can be interpreted that the more fish caught by fishermen, the greater the potential income for fishermen. Fish is defined as an output unit that is able to generate income received by fishermen so that the more fish catches the more the potential of income obtained by fishermen.

Lein, A. A., \& Setiawina, N. D. (2018). Factors affecting the fishermen household income and welfare. International Research Journal of Management, IT and Social Sciences, 5(4), 80-90. https://doi.org/10.21744/irjmis.v5n4.266 
5) Income

According to Sukirno (2006) revenue is the amount of income received by the population for their work performance during a certain period, either daily, weekly, monthly or even yearly. Reksoprayitno (2004: 79) defines: "Revenue can be interpreted as total revenue gained in a given period". Thus it can be concluded that revenue is the amount of income received by members of the community for a certain period of time as remuneration or production factors that have been generated. The most important measure of household income to see fishermen's welfare is household income because some aspects of well-being depend on the level of income of the fisherman. The amount of income of fishermen themselves will affect the basic needs that must be met, namely, food, clothing, housing, and health. Household income level is an important indicator to determine the household level of living. Generally, household income in coastal areas does not come from one source but comes from two or more sources of income. The level of income is thought to be influenced by the fulfillment of the basic needs of fishermen households. Low-income levels require household members to work harder to fulfill their life needs. Family income is expected to reflect the level of wealth and the amount of fishing capital.

6) Household Welfare

To discuss the analysis of the level of welfare, of course, we must know the meaning of prosperity. Prosperous definition according to W.J.S. Poerwadarminta is a safe and prosperous situation. Welfare according to Nurahmad (2009) is a fulfillment of physical and spiritual needs, both inside and outside the working relationship that can directly or indirectly enhance work productivity in a safe and healthy work environment. The purpose of welfare is to create motivation. Welfare is the main reason for workers to join and remain members of the company. Welfare can be measured by using the income received by economic actors. Because with the increase in wages (real and nominal wages) or income, the welfare of workers will increase, this is due to rising income, workers will be better to meet their needs.

\section{Research Methods}

Based on the empirical study, the hypotheses that can be formulated to provide direction for research analysis are:

a) Production costs, technology, sales prices, and fish catches have a positive effect on fishermen's income.

b) The costs of production, technology, sales prices, and fish catches have a positive effect on the welfare of fishermen households.

c) Fisherman's income has a positive and significant impact on the welfare of fishermen households.

d) Fisherman's income mediates the impact of production costs, technology, selling prices and the catch on the welfare of fishermen households.

This study uses primary data sources, namely directly from fishermen. The sampling technique was conducted by Proportionate Probability on 99 respondents. The analytical tool used is descriptive analysis and path analysis processed by SPSS.

The structural equation for path analysis is as follows:

$Y_{1}=\beta_{1} X_{1}+\beta_{2} X_{2}+\beta_{3} X_{3}+\beta_{4} X_{4}+\varepsilon_{1}$

$Y_{2}=\beta_{5} X_{1}+\beta_{6} X_{2}+\beta_{7} X_{3}+\beta_{8} X_{4}+\beta_{9} Y_{1}+\varepsilon_{2}$

Where. $Y_{1}=$ Fisherman's income. $Y_{2}=$ Welfare of fisherman household. $X_{1}=$ Capital. $X_{2}=$ Technology. $X_{3}=$ Fish sales price. $X_{4}=$ Fish catch yields. $\beta 1$ to $\beta 15=$ Path coefficient. $\varepsilon_{1}, \varepsilon_{2}=$ Structural error. The research model can be seen in Figure 1 below: 


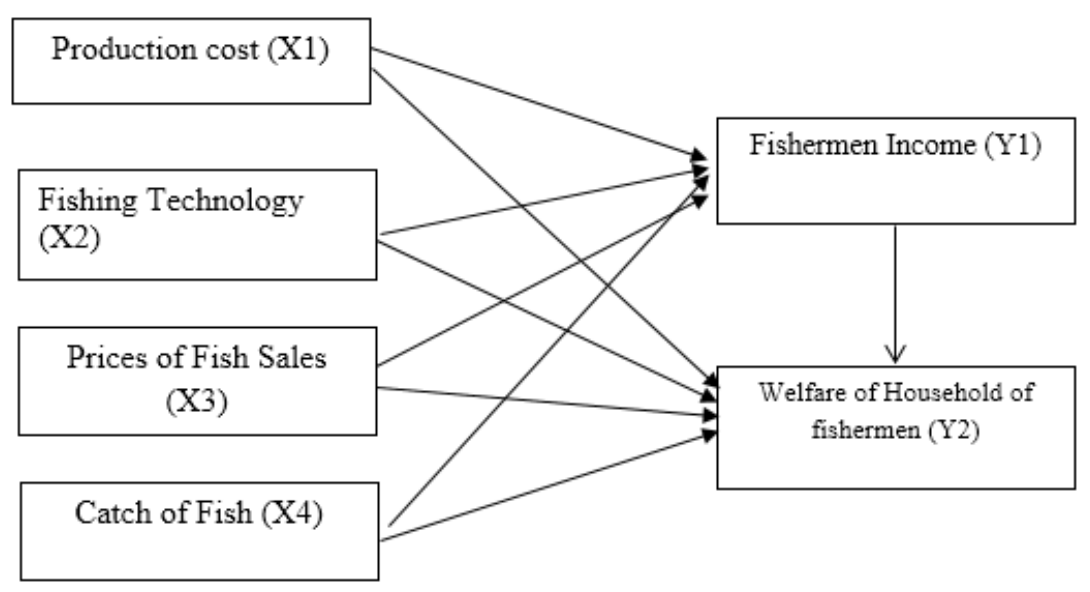

Figure 1. Research Concept

To test how much the role of the variable (Y1) mediates the influence of X1, X2, X3, X4 on Y2, the Sobel test is used. Where the Sobel test uses z test with the following formula:

Sobel Test Formulas: $\mathbf{z}=\frac{a b}{\sqrt{b^{2} S_{a}^{2}+a^{2} S_{b}^{2}}}$

Where: $\mathrm{a}=$ regression coefficient independent variable to regression variable, $\mathrm{b}=$ regression coefficient mediating variable to dependent variable, $S_{a}=$ standard error of estimation from the influence of independent variable to mediating variable, $S_{b}=$ standard error of estimation from the influence of mediating variable on the dependent variable.

\section{Results and Analysis}

\subsection{Description of Research Results}

Research on the income and welfare of fishermen households in East Flores Regency uses 99 respondents. Based on the results of the interviews, it is known that men dominate work as fishermen. This is because the fishing job is very dangerous and uses physical strength. This is in line with the research of Sujarwo (2008) and Setiawan Haryanto (2013) wherein the research it was revealed that the work of a fisherman dominantly conducted by men. In addition, the characteristics of fishermen in East Flores Regency have a customary rule whereby women cannot go to sea when their husbands want to go fishing.

Most of the fishermen in East Flores Regency were Elementary School graduates which amounted to 62.62\%, then graduated from Junior High School 20.20\% and those with high school education were 9.10\% while those who never attended school were $8.08 \%$. This shows that the education of fishermen in East Flores Regency is still low. The results of this study indicate that to be a fisherman does not have to have a high level of education. This is in line with Eka (2009) which confirms that one of the features of the internal sector is the low level of education. The fact is the reason for the fishermen to keep working as a fisherman.

Production costs are an important role in the production. These costs consist of eating, cigarettes, diesel oil, gasoline oil, labor wages, fishing equipment (bait) for a month. Based on the findings in the field, the production cost incurred by the fishermen in East Flores Regency East Nusa Tenggara Province is mostly in the range of IDR. 1,000,000 $1,500,000$ as many as $60.6 \%$. and the lowest frequency is in the production cost of IDR. 2,000,000 as much as $15.2 \%$. The results showed that generally, respondents tend to use the capital below IDR. 2,000,000 as much as $84.8 \%$ this is due to the difficult access to capital for fishermen so that the capital only comes from the sale of fish.

Technology is an important role to increase fish production. The results showed that most respondents still apply simple technology that is $83.83 \%$ while using modern technology $16.17 \%$. The results above show that respondents tend to use traditional technology. This is because access to capital and knowledge of respondents is still minimal to the latest technology to catch fish. The small capital factor is also an obstacle to the transfer of technology from traditional technology to modern technology so that respondents tend to use traditional technology whose prices are

Lein, A. A., \& Setiawina, N. D. (2018). Factors affecting the fishermen household income and welfare. International Research Journal of Management, IT and Social Sciences, 5(4), 80-90. https://doi.org/10.21744/irjmis.v5n4.266 
still affordable. This type of technology will also determine the level of productivity of the use of fishing gear. The more modern the technology used the higher the productivity.

Fish prices in East Flores are strongly influenced by natural and weather conditions. As the concept of demand and supply whereby when the lean season which is usually affected by natural and weather conditions will lead to decreased fishing productivity. This will have an impact on fish prices that rose sharply above the average price. The opposite condition when the fish is in season, where natural conditions and weather support fishing activities so that the catch of fish is abundant and make fish prices tend to be cheap. The results showed that the average price of fish ranged between IDR. 20,000 to IDR. 25,000 at 84.8\%, while the price of fish is IDR. 25,000 to IDR. 50,000 at 15.2\%. But depending on the type of fish caught by fishermen. The types of fish caught by fishermen vary so that the fishermen experience difficulties in determining the price of fish. The difference in the price of fish is a common thing in the lives of fishermen. In this study, the conditions that occurred in East Flores Regency at the time of research were not in the fishing season so that the price of fish offered by fishermen was higher than the price of fish during the peak season. The price of fish during the famine season has increased because the fishermen have no other way to cover the capital used during fishing. It is intended that fishermen in East Flores Regency would still benefit from the sale of fish.

Fish catch is a commodity that can generate income for fishermen. The more fish catches the fishermen get, the greater their potential income. Every fisherman in East Flores Regency has different fish catches. The results showed that the catch of fishermen of East Flores Regency varies between fellow fishermen. From the result of research, there are 58 or $58,6 \%$ of fishermen who get $200-249 \mathrm{~kg}$ fish per month, 33 (33,3\%) fishermen who get less than $250 \mathrm{~kg}$ of fish per month and $8(8,1 \%)$ fishermen get $150-199 \mathrm{~kg}$ of fish per month.

Income is one of the indicators for measuring the level of community welfare. To analyze the welfare of fishermen household by income indicator, it was used one indicator i.e. the total of respondents profits earned from the sale of fish plus other income of the respondent and other family members. The findings showed that most respondents have an income ranging between IDR. 1.500 .000 to IDR. 2,000,000 or $76.8 \%$. then the respondents who have an income ranging between IDR. 2.000,000 to IDR.2.500.000 was 8.1\%, while 15.2\% have incomes of IDR.2.500.000. Respondents' income comes from the number of profits obtained from the sale of fish by $80 \%$, while $20 \%$ comes from other incomes and family members who work outside the fishing sector. This shows that activities as fishermen become the dominant factor in the source of household income.

The results showed that the welfare condition of fishermen households in East Flores Regency can be said to be above the poverty line. This is evident from the amount of income and expenditure of fishermen households in the range of the East Nusa Tenggara Province Minimum Wage (UMR) in 2017, which is IDR. 1,500,000. in addition, it is also the perception of the fishermen associated with indicators of health, education, security, living conditions, love, and social and family relationships that make a positive contribution to the welfare of fishermen household.

\subsection{Discussion of Research Results}

The cost of production for the fishing community is very important in business development. The fishermen can survive and develop well and dynamically if accompanied by access to production costs. Production costs can affect the production process, affect the purchase of fishing equipment, and hamper the work process. Cost of production is the cost in the form of money that is the amount of money held to be used for operational activities. The money is used to finance the production costs. Thus the cost of production is in the form of money and all expenditures used for production process activities can be calculated up to the marketing activities of business results. While the capital is capital in the form of equipment which is also called business assets.

In the life of fishermen, the price of marine fish is not always fixed so that the income of fishermen is not always stable. For example, during the fish season, fish prices tend to be low because the fish are so abundant. However, when the season is famine, fish prices tend to rise and have an impact on decreasing demand due to high fish prices. Prices on fish offered by producers to consumers have become relatively stable and have not increased, meaning that fishermen are willing to not gain more than the sale of the fish.

The results showed that the average net income of fishermen was IDR. 1,500,000, exactly the same as the regional minimum wage (UMR) prevailing in East Flores Regency. Nevertheless, almost all respondents have a perception that the income they generate is enough to prosper the family economy.

In this study, there are two dependent variables, namely fisherman income (Y1) and fisherman household welfare (Y2). From both dependent variable, fisherman income variable (Y1) value equal to 0,987 so that the influence of an 
independent variable on the dependent variable is strong. While the community welfare variable (Y2) is worth 0.934 so that the influence of the independent variable on the dependent variable is relatively strong.

Based on the result of path analysis can be explained that production cost has the positive and significant effect on fisherman income. This is indicated by the path coefficient of 0.290 and the significant level less than 0.05 with the value of P-value of 0.000 . This means that the higher the production cost of fishermen, the higher the fisherman's income. Fishermen who use more modern technology will have a greater income compared to fishermen who use simple technology. Fishing technology has a positive and significant impact on fisherman's income. This is indicated by the path coefficient of 0.369 with a significance level of less than 0.05 with P-value of 0.000 .

The selling price of fish has a positive and significant effect on the fisherman's income with the path coefficient of 0.234 and the significance level is greater than 0.05 with the P-value of 0,024 . This proves that the higher the selling price of the fish, the higher the fisherman's income. Fishing results have a positive and significant impact on fisherman's income. This is indicated by the path coefficient of 0.189 and the significant level of less than 0.05 with the P-value of 0.000. This means that the higher the yield of fishing, the higher the fishermen's income.

Production costs have a positive and significant effect on the welfare of fishermen households. This is indicated by the path coefficient of 0.419 and the significant level of less than 0.05 with the P-value of 0.000 . This means that the higher the production cost used in fishing, the better the welfare of fishermen households. The technological variables used in catching fish have a positive and significant impact on the welfare of fishermen households. This is indicated by the path coefficient of 0.278 with a significance level of above 0.05 with P-value of 0.000 . This means that the more sophisticated the technology used in fishing, the better the welfare of fishermen households.

Sales prices have a positive and significant effect on the welfare of fishermen households with a path coefficient of 0.096 with a significance level greater than 0.05 with a P-value of 0.040 . This means that the higher the price of fish sales, the higher the welfare of the fishermen households. Fishing results have a positive and significant impact on the welfare of fishermen households. This is indicated by the path coefficient of 0.186 and the significant level less than 0.05 with the value of P-value 0.000. This means that the more fish catches the fishermen get, the higher the welfare of the fishermen households. Fisherman income variables have a positive and significant effect on the welfare of fishermen households with path coefficients of 0.131 with a significant level of less than 0.05 , which is 0.005 . This shows that the higher the income of fishermen, the more increasing the welfare of fishermen households.

The result of the direct effect of X1 on $\mathrm{Y} 2$ is 0,419 . whereas the indirect effect $\mathrm{X} 1$ through $\mathrm{Y} 1$ on $\mathrm{Y} 2$ is $0.419 \mathrm{x}$ $0.131=0.054$. The total effect of X1 on Y2 is the direct effect coupled with the indirect effect of $0.419+0.054=$ 0.473 . This result shows that indirectly X1 through Y1 has a significant effect on Y2.

The direct influence of $\mathrm{X} 2$ on $\mathrm{Y} 2$ is 0.278 while the direct effect of $\mathrm{X} 2$ through $\mathrm{Y} 1$ on $\mathrm{Y} 2$ is $0.278 \times 0.131=0.036$. The total effect of X2 on Y2 is the direct effect plus the indirect effect of $0.278+0.036=0.314$. This result shows that indirectly $\mathrm{X} 2$ through $\mathrm{Y} 1$ has a significant effect on $\mathrm{Y} 2$.

The direct effect of $\mathrm{X} 3$ to $\mathrm{Y} 2$ is 0.096 while the direct effect of $\mathrm{X} 3$ through $\mathrm{Y} 1$ on $\mathrm{Y} 2$ is $0.096 \times 0.131=0.012$. The total effect of X3 on Y2 is the direct effect plus the indirect effect of $0.096+0.012=0.108$. This result shows that indirectly X3 through Y1 has a significant influence on Y2.

The direct effect of $\mathrm{X} 4$ to $\mathrm{Y} 2$ is 0.186 while the direct effect of $\mathrm{X} 4$ through $\mathrm{Y} 1$ on $\mathrm{Y} 2$ is $0.186 \times 0.131=0.024$. The total effect of $\mathrm{X} 4$ on $\mathrm{Y} 2$ is the direct effect coupled with the indirect effect of $0.186+0.024=0.21$. This result shows that indirectly $\mathrm{X} 4$ through $\mathrm{Y} 1$ has a significant influence on $\mathrm{Y} 2$.

The direct effect of $\mathrm{X} 4$ on $\mathrm{Y} 2$ is 0.186 whereas the direct influence of $\mathrm{X} 4$ through $\mathrm{Y} 1$ on $\mathrm{Y} 2$ is $0.186 \times 0.131=$ 0.024 . The total effect of $\mathrm{X} 4$ on Y2 is the direct effect coupled with the indirect effect of $0.186+0.024=0.21$. This result shows that indirectly $\mathrm{X} 4$ through $\mathrm{Y} 1$ has a significant influence on $\mathrm{Y} 2$.

\section{Conclusion}

The purpose of this study is to analyze the factors that affect the income and welfare of fishermen households in East Flores Regency, Indonesia. In general, the results of the analysis provide empirical support for the hypotheses formulated. The results show that the cost of production, technology, selling price and fishing result have a positive and significant influence on income and welfare of fisherman household, fisherman income mediates the influence of production cost, technology, selling price and the result of fishing on the household welfare of fisherman.

Suggestions that can be given: 1) To encourage an increase in fishermen's income, it is expected that the East Flores Regency government through the Department of Fisheries in collaboration with other relevant agencies to find solutions to the problems of working capital by opening access to get working capital for the welfare of fishermen. It should be done in collaboration with cooperatives or bank and non-bank financial institutions. 2) To encourage

Lein, A. A., \& Setiawina, N. D. (2018). Factors affecting the fishermen household income and welfare. International Research Journal of Management, IT and Social Sciences, 5(4), 80-90. https://doi.org/10.21744/irjmis.v5n4.266 
fishermen's ability, the Government of East Flores Regency, especially the Fisheries Department is expected to provide guidance and development of technological improvement capability in fishing with the right technology. 3) The use of labor by each group of fishermen should be adjusted to the needs so that it will more effectively reduce costs of fishing because the additional labor is not professional. 4) The equipment used by fishermen, in general, is still minimal and traditional so that the yields of catches often cannot cover the costs used for household consumption.

Conflict of interest statement and funding sources

The authors declared that they have no competing interest. The study was financed by personal funding.

Statement of authorship

The authors have a responsibility for the conception and design of the study. The authors have approved the final article.

\section{Acknowledgments}

The authors would like to thank the editor of IRJMIS for their support, advice, and valuable time. 


\section{References}

Akazawa, Y., Kubo, M., Zhang, R., Matsumoto, K., Yan, F., Setiawan, H., ... \& Ogino, K. (2013). Inhibition of arginase ameliorates experimental ulcerative colitis in mice. Free radical research, 47(3), 137-145.

Ani, S. W., Sundari, M. T., \& Antriyandarti, E. (2013). Pengembangan Desa Wisata Rumah Dome Berbasis Agroindustri Pangan Lokal (Kajian Diversifikasi Ketela Pohon di Desa Wisata Rumah Dome Prambanan). Agriekonomika, 2(2), 117-122.

Daulay, M. Analisis Faktor-Faktor Yang Mempengaruhi Pendapatan Nelayan Di Kabupaten Langkat (Master's thesis).

Joesron, T. S., \& Fathorrozi, M. (2003). Teori Ekonomi Mikro. Salemba Empat. Jakarta.

Kotler, P. (2001). Manajemen Pemasaran: Analisis, Perencanaan, Implementasi, dan Kontrol. jakarta: PT Prehallindo.

Larantika, A. A. A. D., Zauhar, S., Makmur, M., \& Setyowati, E. (2017). Collaboration as a Strategy for Poverty Alleviation. International Journal of Social Sciences and Humanities (IJSSH), 1(3), 40-48.

Maba, W., Perdata, I. B. K., \& Astawa, I. N. (2017). Constructing Assessment Instrument Models for Teacher's Performance, Welfare and Education Quality. International Journal of Social Sciences and Humanities (IJSSH), 1(3), 88-96.

Miller, R. L., \& Meiners, R. E. (2000). Teori mikroekonomi intermediate. Penerjamah Haris Munandar, PT. Raja Grafindo Persada, Jakarta.

Nurachmad, M. (2009). Cara Menghitung Upah Pokok, Uang Lembur, Pesangon, \& Dana Pensiun untuk Pegawai dan Perusahaan. VisiMedia.

Putri, Y. E., Rosa, Y. D., \& Trisnawati, M. Pengaruh Modal Kerja, Tenaga Kerja, Jam Kerja terhadap Pendapatan Nelayan Tradisional di Nagari Koto Taratak Kecamatan Sutera Kabupaten Pesisir Selatan. Pendidikan Ekonomi, 2(2).

Rambe, A. (2004). Alokasi Pengeluaran Rumah Tangga dan Tingkat Kesejahteraan (Kasus di Kecamatan Medan Kota, Sumatera Utara)[tesis]. Bogor: Sekolah Pascasarjana, Institut Pertanian Bogor.

Salim, A. (1999). Analisis Tingkat Pendapatan Nelayan dan Faktor-Faktor yang mempengaruhinya di Kecamatan Syiah Kuala Kotamadya Banda Aceh (Doctoral dissertation, Tesis S2 PPS Usu, Medan).

Salim, E. (1977). Perencanaan pembangunan dan perataan pendapatan. Yayasan Idayu.

Sugiana, I. G. N., Sadguna, D. N., Tonga, Y., \& Kaca, I. N. (2018). The Study on Farmers Welfare. International Journal of Life Sciences (IJLS), 2(1), 29-41.

Sukirno, S. (2004). Makroekonomi teori pengantar. Jakarta: PT raja Grafindo persada.

Lein, A. A., \& Setiawina, N. D. (2018). Factors affecting the fishermen household income and welfare. International Research Journal of Management, IT and Social Sciences, 5(4), 80-90. https://doi.org/10.21744/irjmis.v5n4.266 


\section{Biography of Author}

\begin{tabular}{|l|l|}
\hline My name is Alberto A. R. Lein often called Albert, I was born on 01, April 1993. I am \\
the first child of four siblings. In 2011 I graduated from high school and went to college \\
to the University of Flores Ende majoring in the Faculty of Law. After graduating from \\
the University of Flores Ende in 2015, in 2016 I continued my study master at Udayana \\
University Denpasar study program Master of Economics
\end{tabular}

